\title{
Snow and albedo climate change impacts across the United States Northern Great Plains
}

\author{
S. R. Fassnacht ${ }^{1,2,3}$, M. L. Cherry ${ }^{1, a}$, N. B. H. Venable ${ }^{4}$, and F. Saavedra ${ }^{4}$ \\ ${ }^{1}$ ESS-Watershed Science, Colorado State University, Fort Collins, Colorado 80523-1476, USA \\ ${ }^{2}$ Cooperative Institute for Research in the Atmosphere, Fort Collins, Colorado 80523-1375, USA \\ ${ }^{3}$ Geospatial Centroid at CSU, Fort Collins, Colorado 80523-1019, USA \\ ${ }^{4}$ EASC-Watershed Science, Colorado State University, Fort Collins, Colorado 80523-1482, USA \\ a now at: Department of Geography, University of Victoria, David Turpin Building B203, 3800 Finnerty Road (Ring Road), \\ Victoria, British Columbia V8P 5C2, Canada
}

Correspondence to: S. R. Fassnacht (steven.fassnacht@ colostate.edu)

Received: 26 February 2015 - Published in The Cryosphere Discuss.: 26 June 2015

Revised: 17 November 2015 - Accepted: 10 January 2016 - Published: 10 February 2016

\begin{abstract}
In areas with a seasonal snowpack, a warmer climate could cause less snowfall, a shallower snowpack, and a change in the timing of snowmelt, all which could reduce the winter albedo and yield an increase in net short-wave radiation. Trends in temperature, precipitation (total and as snow), days with precipitation and snow, and winter albedo were investigated over the 60-year period from 1951 to 2010 for 20 meteorological stations across the Northern Great Plains. This is an area where snow accumulation is shallow but persistent for most of the winter (November to March). The most consistent trends were minimum temperature and days with precipitation, both of which increased at a majority of the stations. Among the stations included, a decrease in the modelled winter albedo was more prevalent than an increase. There was substantial spatial variability in the climate trends. For most variables, the period of record used influenced the magnitude and sign of the significant trends.
\end{abstract}

\section{Introduction}

While global annual temperatures have increased by $0.74{ }^{\circ} \mathrm{C}$ in the past century and $1.3^{\circ} \mathrm{C}$ in the past 50 years, these temperature increases are not consistent across the globe (IPCC, 2007). In some locations, temperatures are increasing much more rapidly than the global average rate, and increases are not uniform for annual maximum and minimum temperatures. Trends in annual minimum temperatures are important for snowpack properties. Snowfall and snowpack trends are an important issue in semi-arid to arid climates where water demand already surpasses supply (Stewart, 2009).

In non-polar regions, an overall warmer climate could yield less snowfall, a shallower snowpack, and a change in the timing of the snowmelt (Stewart, 2009). The western United States has already seen earlier snowmelt and peak discharge in snow-dominated river systems of up to 20 days earlier (Stewart, 2009). The western United States has also seen widespread declines in springtime snow water equivalent (SWE) from 1925 to 2000 (Mote et al., 2005).

Numerous studies have examined the snow cover and its variability across the Northern Hemisphere, with most highlighting a decrease over the period of record. Station data for North America have shown that the end date of snow cover has not changed from 1980 to 2006, although some temperatures have been warming for the same region (Peng et al., 2013). Using up to eight sources, including station and modelled data, it is evident that the March and April snowcover extent (SCE) values were constant or slightly decreasing from about 1960 to the early 1980s, then a decrease during the 1980 s, followed by an increase in the early 1990 s (Brown and Robinson, 2011). After that, the March SCE was relatively stable during 2010, but it decreased in April (Brown and Robinson, 2011).

There has also been a decrease in precipitation as snow across the western United States (Knowles et al., 2006). Decreases are amplified when the average wintertime temper- 
atures remain around $0{ }^{\circ} \mathrm{C}$ (Knowles et al., 2006). The ratio of precipitation as snow has also been decreasing across the northeastern United States and the contiguous United States region (Huntington et al., 2004; Feng and $\mathrm{Hu}, 2007$, respectively). Over some of the previously studied regions, there has been both an overall decrease in the amount of snowfall and an increase in the amount of annual precipitation. These trends are correlated to winter temperature increases and are a cause for concern as snow cover acts as a control for summer soil-water storage and without long periods of snow cover, croplands like those found across the Northern Great Plains will become drier (Feng and Hu, 2007; Stewart, 2009). Somewhere between 90 and 120 snow-covered days are observed in the Northern Great Plains, with a thin maximum SWE of between 20 and $40 \mathrm{~mm}$. Brown and Mote (2009) used a number of climate models to simulate snowpack changes and found that the largest decrease in the future was for snow-covered days, the maximum SWE decreased only a small amount.

Snow cover, which has been directly linked to the seasonal snowpack, is an important part of the energy budget due to its low thermal conductivity and high albedo (Stewart, 2009). Similarly, the snow albedo feedback is a concept used in climate models to define the sensitivity of the atmospheric energy balance to net solar radiation due to a change in snowpack albedo (Qu and Hall, 2006). Reductions in the albedo of a snowpack surface, such as due to the presence of dust, can drastically increase rate of melt and for deep snowpack, result in snow-free conditions a month or more earlier than clean snow conditions (e.g. Painter et al., 2007). The increased absorption of solar radiation due to a decreased albedo is much more important in the melting of snow than the small increases in long-wave radiation due to temperature increases (Painter et al., 2010).

Changes in the amount of precipitation as snowfall and the number of days with snowfall are both important for the water and energy budget of an area. Reductions in overall amount of precipitation as snow should likely lower the depth of the snowpack and could possibly decrease the persistence of snow cover which could decrease the overall winter albedo. The decreased albedo would increase the absorption of the incoming solar radiation. A reduction in the number of days with snowfall would reduce the amount of fresh snow and therefore reduce the overall albedo of the snowpack, resulting in an increase in the amount of radiation that is absorbed.

The objectives of this paper are to determine (1) if the amount of precipitation falling as snow is changing, (2) if the number of days with snowfall is changing, and (3) if these changes impact modelled albedo over the winter period, which is defined as November to March. Annual precipitation and temperature changes will also be evaluated. This investigation will also focus on two stations in close proximity to one another to examine small-scale spatial changes and the influence of the length of record.

\section{Data}

For this work the Northern Great Plains (NGP) area is defined as the western parts of Kansas, Nebraska, and South Dakota, as well as the eastern parts of Colorado and Wyoming (Fig. 1). This area represents a transition from the more water-abundant east to the more arid region bordering the Front Range of the Rocky Mountains, and as such plays an important role in crop production in the United States http://www.globalchange.gov/. Snowpack accumulation is shallow but persistent for most of the winter. The Köppen-Geiger classification for the area is mostly semi-arid (BSK), with small parts of the humid continental (DFA) classification (Peel et al., 2007).

Twenty stations (Fig. 1) were identified for this region that had less than $30 \%$ of all years excluded due to missing data, where missing years were those with more than 14 days of missing data (Reek et al., 1992). The stations were located from 39.4 to $44.7^{\circ} \mathrm{N}$ latitude and from 99.8 to $105^{\circ}$ longitude, with elevation ranging from 733 to $1880 \mathrm{~m}$ a.s.l. Daily data, including of maximum temperature, minimum temperature, precipitation, and snowfall, were retrieved for the period from 1951 to 2010 from the National Climatic Data Center (NCDC) www.ncdc.noaa.gov, and summarised for the annual analysis.

The stations were all part of the NCDC cooperative (COOP) network. Often such stations are moved, especially over a long period of record, such as the 60 years examined here (e.g. Groisman and Legates, 1994; Groisman et al., 1996; Peterson et al., 1998). Such moves can created discontinuities. As such, nine of the stations (denoted by an asterisk in Figs. 1, 2, 3) were part of the U.S. Historical Climatology Network (USHCN) that are considered a highquality data set of basic meteorological variables (Menne et al., 2015). The station metadata were reviewed to examine station moves and thus possible discontinuities in the record. All nine of the USHCN stations were moved over 60 years of investigation but these moves were usually less than several kilometres. Three of the remaining stations (Chadron, North Platte, and Yuma) were not moved and thus considered consistent. Six stations (Belle Fourche, Benkelman, Goodland, Lexington, Newell, and Ogallala) were moved less than $0.5 \mathrm{~km}$ and most only $150 \mathrm{~m}$. Edgemont was moved in 2009 at the end of the period of investigation; thus this was not considered to bias the trend analysis. Some of the station moves appeared to be back to or in close proximity of previous locations. This appears to be the case for Sterling that was moved in 1983 and back in 2004. 


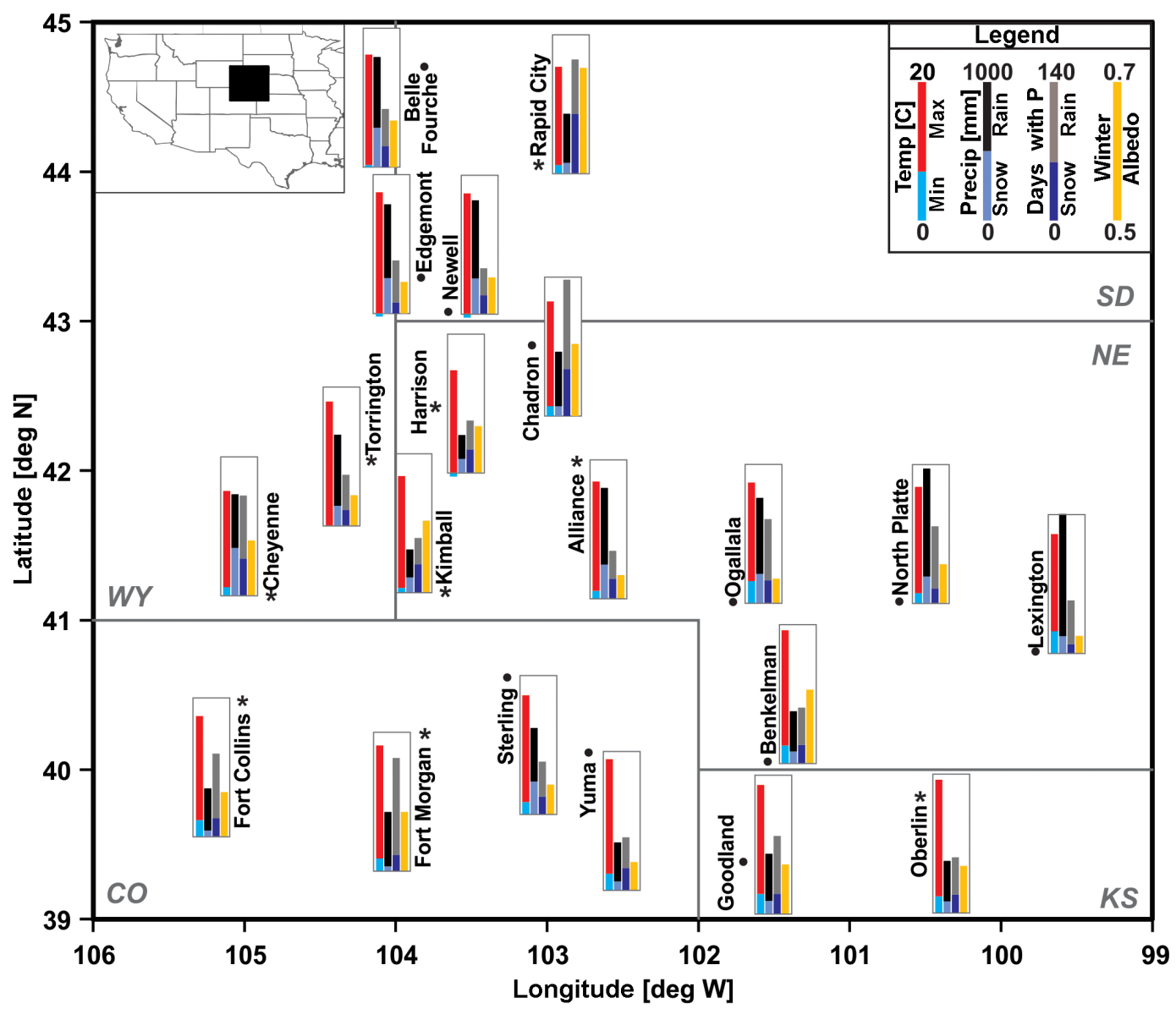

Figure 1. Location map and average climate from 1951 to 2010 for the 20 study stations in the Northern Great Plains. The annual climate summary includes the temperature (temp) as daily maximum (max) and minimum (min), precipitation (precip) as the sum of rain and snow shown separately, days with precipitation (days with $P$ ) as the sum of days with rain and days with snowfall shown separately, and the winter albedo. The precipitation as snow is the amount of precipitation when fresh snow was observed, as defined by Huntington et al. (2004); the days with snowfall are the days when fresh snow was observed. The winter albedo is modelled. The nine stations that are part of the U.S Historical Climate Network (HCN) are identified with an asterisk.

\section{Methods}

For each station, the annual average maximum and minimum temperature were calculated for each year in degrees Celsius. The total precipitation $(\mathrm{mm})$ and snowfall $(\mathrm{mm})$, from precipitation as snow, as well as the number of days with precipitation and snow, were also calculated for each year (Huntington et al., 2004). The amount of precipitation as snow was the total daily precipitation when snowfall was observed. Air temperature was not used as a threshold between rain and snow, as this varies based on climate (Fassnacht and Soulis, 2002; Fassnacht et al., 2013).

We did not attempt to correct for snowfall that melted before being measured (Huntington et al., 2004). This means that snowfall that fell and melted before it was measured was counted as rainfall. This study does not take into consideration days that may have had mixed precipitation (where both rain and solid precipitation fall in the same day). This will overestimate the amount of snowfall since it includes days with both rain and snow entirely as snowfall. However, since precipitation gauges are less efficient at measuring snowfall than rainfall there is an error both underestimating and overestimating the total amount of snowfall. There was no attempt made to quantify the error caused by the assumptions in this study (see Huntington et al., 2004; Knowles et al., 2006). While trends have been observed in wind speed (e.g. Hoover et al., 2014), it was assumed these were limited across the study domain and that there was no trend in the amount of undercatch. In particular, wind-induced undercatch (e.g. Yang et al., 1998) was not computed since wind data were not available. Similar assumptions have been applied to studies in other regions with similar climate, such as Mongolia (Fassnacht et al., 2011).

Various snow albedo $\left(\alpha_{\mathrm{s}}\right)$ models have been created with different data requirements. The simplest models are a threelinear-segment shallow snowpack model (Gray and Landine, 


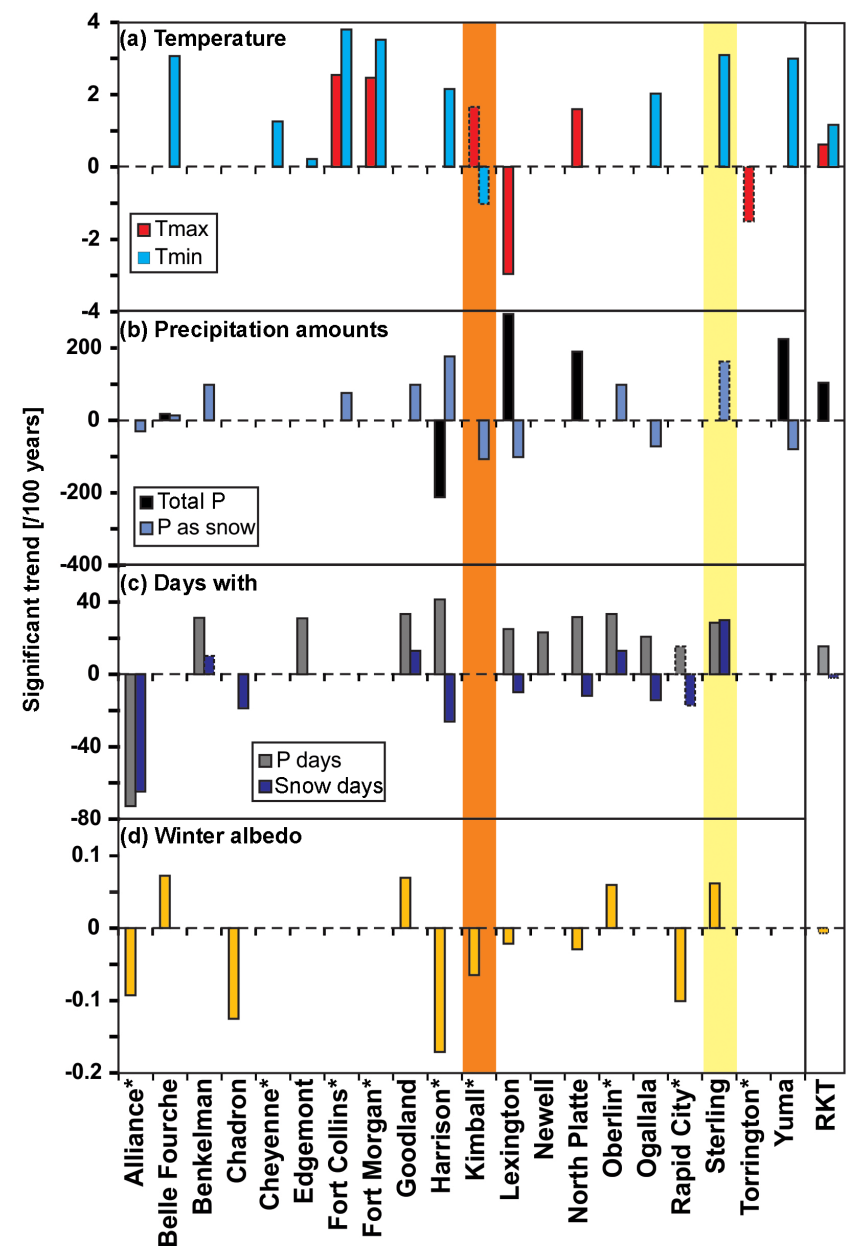

Figure 2. Significant climatic trends at the 20 stations and for the seven variables summarised in Fig. 1 for the period from 1951 to 2010, shown per century. Significant trends are presented at the $p<0.05$ level, except for trends shown with a dashed border which are at the $p<0.10$ level. Trends from the Regional Kendall test (RKT) are shown on the right. The Sterling, Colorado (yellow), and Kimball, Nebraska (orange), stations are highlighted as they are subsequently compared in Figs. 4 and 5. The nine stations that are part of the U.S. Historical Climate Network (HCN) are identified with an asterisk.

1987) and a first-order decay model (Verseghy, 1991), originally derived by the U.S. Army Corps of Engineers (1956). Other models exist, such as the sub-model used in the CROCUS snow model, where $\alpha_{\mathrm{s}}$ varies as a function of wavelength for three spectral bands and snow particle size (Brun et al., 1992; Vionnet et al., 2012). The Greuell and Konzelmann (1994) formulation considers the density of snow and the interaction of snow and ice albedos. The SNICAR albedo model (Flanner and Zender, 2005; Flanner et al., 2007) further considers surface temperature and near-surface temperature gradients (Flanner and Zender, 2006) to simulate changes in snow particle size and shape. However, only precipitation, snowfall, snow on the ground, and temperature data were available at a daily time step for this current study; thus the simple $\alpha_{\mathrm{s}}$ decay model was used to determine trends.

Daily albedo was modelled over the winter period (November to March) using meteorological data (temperature, precipitation, and snow on the ground). Since observations of albedo and surface characteristics were not available, a time-variant first-order decay model was used. This model takes the form:

$\alpha_{\mathrm{s}(t)}=\left[\alpha_{\mathrm{s}(t-1)}-\alpha_{\mathrm{s}-\min }\right] e^{-k \Delta t}+\alpha_{\mathrm{s}-\min }$,

where $\alpha_{\mathrm{S}(t)}$ and $\alpha_{\mathrm{s}(t-1)}$ are the albedo at the current and previous time step, $t, \alpha_{\mathrm{s}-\min }$ is the minimum allowable albedo, $k$ is a decay coefficient, and $\Delta t$ is the time step (Verseghy, 1991). This model is incorporated into the Canadian Land Surface Scheme (Verseghy, 1991) to model snow conditions (Brown et al., 2006). In this paper, the decay (0.01 per hour converted to a daily rate) used by Verseghy (1991) was implemented. It uses three conditions: (1) for fresh snow, $\alpha_{\mathrm{s}(t)}$ is set at $0.84,(2)$ for dry snow (no melt), $\alpha_{\mathrm{s}(t)}$ decays to an $\alpha_{\mathrm{s}-\min }$ of 0.70 , and (3) for melting snow, $\alpha_{s(t)}$ decays to an $\alpha_{\mathrm{s}-\min }$ of 0.50 . Using the same albedo model as in the Canadian Land Surface Scheme, Langlois et al. (2014) proposed a threshold of $0.5 \mathrm{~cm}$ to reset the albedo to 0.84 . Herein, fresh snow was considered to reset the albedo to 0.84 when at least $2.54 \mathrm{~cm}$ of snowfall was observed over a day, since this was the resolution of fresh snow depth measurements. When no snow was present, a soil albedo of 0.20 was used.

The significance of each climatological trend was determined using the Mann-Kendall test (Gilbert, 1987). This is a robust non-parametric test that does not assume a specific distribution of the data nor is it influenced by extreme values/outliers or missing values. For all stations, trends were analysed from the entire period of record (1951-2010). For the Sterling, Colorado, and Kimball, Nebraska, stations, the periods from 1951 to 1980 and from 1981 to 2010 were also investigated to see if there was a difference in the changes in trends over a shorter time period (Venable et al., 2012). When a trend was significant, the rate of the change was estimated using the Sen's slope estimator, which is the median slope of all pairs analysed, giving the overall rate of change. For this analysis, the MAKESENS macro developed for Excel spreadsheets was used (Salmi et al., 2002) to identify trends at both the $p<0.05$ and $p<0.10$ level.

To further investigate changes at these two locations over the later 30 years, the North American Regional Reanalysis (NARR) data were also evaluated. Monthly data were acquired from the NARR data set from the NOAA/OAR/ESRL PSD, Boulder, Colorado, USA, on their website: http://www. esrl.noaa.gov/psd/ (Mesinger et al., 2006). The NARR data are a combination of modelled (the National Centers for Environmental Prediction Eta model) and assimilated (regional data assimilation system, RDAS) station data at a spatial resolution of $32 \mathrm{~km}$ available for the period from 1979 to present. The point values from the two comparison stations (Sterling and Kimball) were extracted by location. The 


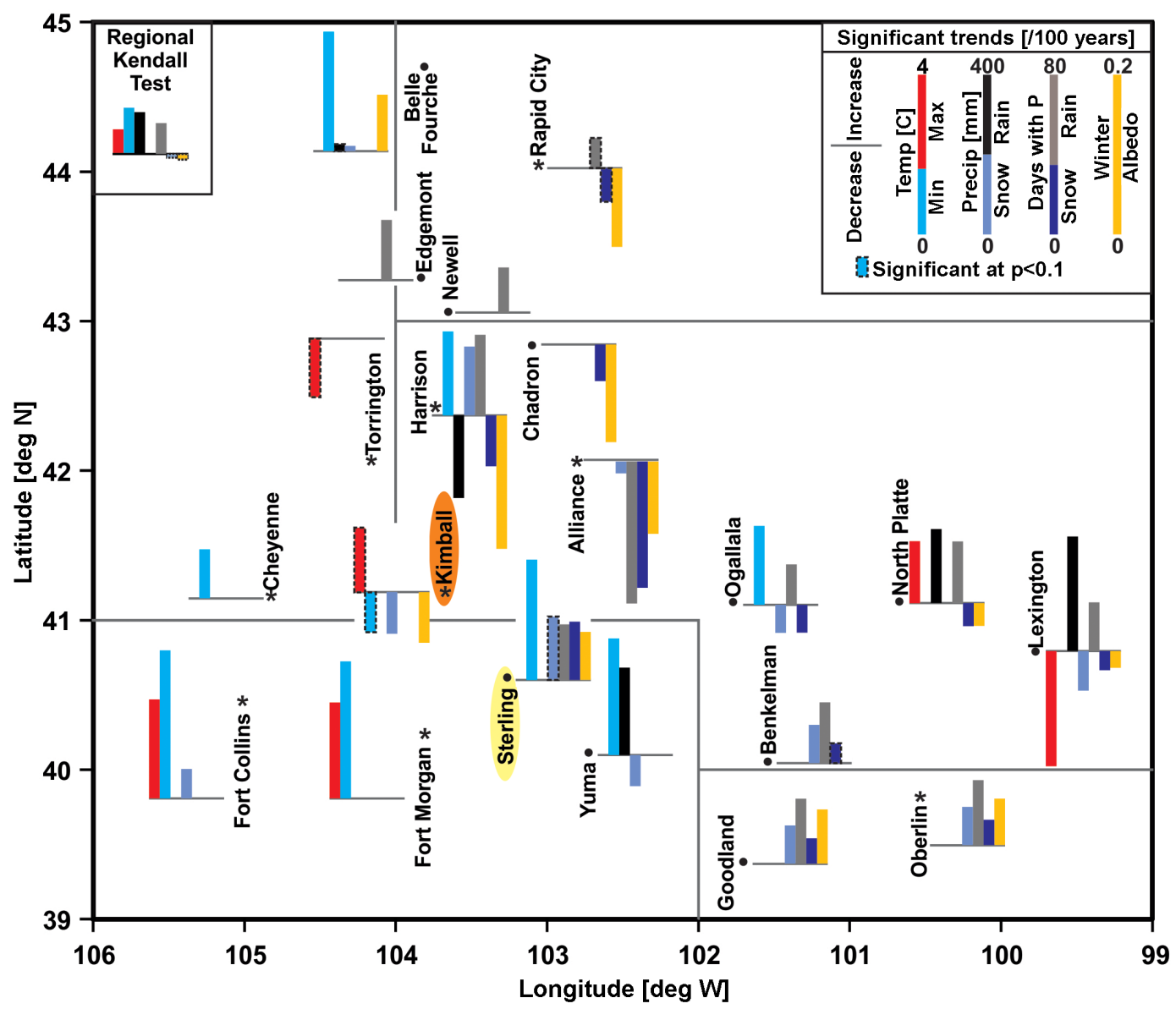

Figure 3. The spatial distribution of the climatic trends at the $p<0.05$ level for the period from 1951 to 2010, shown per century. Trends shown with a dashed border are at the $p<0.10$ level. Significant RKT trends are shown in the top left. Sterling and Kimball stations are highlighted.

yearly summary by calendar year for air temperature and precipitation and from November to March from the albedo data set was tested for trend analysis.

Trends are often computed to assess regional climate patterns. The Regional Kendall test (RKT of Helsel and Frans, 2006) combines a number of stations in close proximity to estimate the Mann-Kendall significance and Sen's slope rate of change. Since Clow (2010) used RKT to assess trends for station groups over tens to hundreds of kilometres in the mountain of Colorado, it is also used here as the terrain in the NGP is less complex that in the mountains and the climate should be less varying.

\section{Results}

Average annual maximum $\left(T_{\max }\right)$ and minimum $\left(T_{\min }\right)$ temperatures varied by less than $5^{\circ} \mathrm{C}$, ranging from 14.3 to 19.2 and from -0.5 to $3.2^{\circ} \mathrm{C}$, respectively, while annual total precipitation $(P)$ varied almost fourfold from 277 to $1016 \mathrm{~mm}$ and precipitation as snow ( $P$ as snow) sixfold from 46 to
$349 \mathrm{~mm}$ annually (Fig. 1). The range in the number of days with precipitation ( $P$ days) and snowfall (snow days) varied similarly, but the average modelled winter albedo only varied from 0.53 to 0.6 (Fig. 1).

Climate trends were generally spatially variable, with warming of minimum temperatures and more days with precipitation illustrating the most consistent trends across the 20 stations (Figs. 2, 3). Minimum temperatures increased at nine stations averaging $2.74^{\circ} \mathrm{C}$ per century, with significant $T_{\min }$ cooling only at Kimball. Eleven stations saw an average increase of 28.3 days with precipitation per century, while only Alliance had fewer precipitation days. $T_{\max }$ trends were fewer (four significant and two less significant), with four warming and two cooling. Precipitation totals increased at four locations by an average of $182 \mathrm{~mm}$ per century and decreased at one. Changes in the amount of precipitation as snow are more prevalent, with seven stations increasing by an average of $103 \mathrm{~mm}$ per century, and five decreasing by an average of $78 \mathrm{~mm}$ per century. Four stations had more snow days by an average of 16.6 per century, while seven saw an 
average of 23.2 fewer snow days per century. Alliance was the only station with a decrease in both $P$ and snow days, and these were the largest changes. Albedo increased at four stations by an average of $6.6 \%$ per century and decreased at seven stations by an average of $8.6 \%$ per century.

There are some identifiable spatial patterns in the climate trends. For example, in the southwest parts of the NGP, $T_{\max }$ and/or $T_{\min }$ increased at most stations (Fig. 3), but there was a decrease in $T_{\max }$ at Torrington and in $T_{\min }$ at Kimball, respectively. Other spatially coherent areas included increasing $P$ totals and days with $P$ in the east, and increasing $P$ as snow, days with $P$, and days with snowfall in the southeast, with some corresponding increases in albedo. However, adjacent stations showed decreasing snow and some decreasing albedo. In the north and northwest parts, snow days and albedo decreased, but Belle Fourche showed the opposite trend. In the south at Sterling, Goodland, and Oberlin, the modelled winter albedo increased (Fig. 3).

Significant trends were observed with the RKT for $T_{\max }$ (rate of $0.625^{\circ} \mathrm{C} / 100$ years), $T_{\min }$ (rate of $1.17^{\circ} \mathrm{C} / 100$ years), $P$ amount (rate of $105.3 \mathrm{~mm} / 100$ years), and days with $P$ (rate of $15.6 / 100$ years), while days with snowfall decrease (rate of $-1.82 / 100$ years) and albedo decreases $(-0.007 / 100$ years) were only significant at the $p<0.10$ level (Figs. 2, 3). These were similar to the averages of the individual stations. The RKT trends in $P$ as snow were not significant (Fig. 2). The magnitude of regional trends tended to be much less than what was observed at individual stations as no systematic trends were observed across the entire domain (Fig. 3).

Sterling, in northeast Colorado, and Kimball, in southwest Nebraska, are $73 \mathrm{~km}$ apart with an elevation difference of $380 \mathrm{~m}$ (highlighted in Figs. 2 and 3). Opposite trends in winter albedo were estimated (Fig. 4d), in part as a function of differences in temperature (Fig. 4a), precipitation as snow (Fig. 4b), and days with precipitation and snow (Fig. 4c).

Average temperature trends were similar for the station and NARR data (Table 1), while total precipitation was decreasing from the station data yet increasing from the NARR data. Precipitation as snow was decreasing at twice and more than 10 times the rate for the station data, compared to the NARR data at Kimball and Sterling, respectively. Albedo trends were of opposite sign and different magnitude between the two data sets. The minimum station temperature and average NARR temperature trends at Sterling were significant; no other variable had a significant trend for both the station and NARR data sets (Table 1).

\section{Discussion}

The RKT trends showed increases for four variables (at $p<0.05$ level) and decreasing trends $(p<0.10$ level) for two variables (Fig. 2) that were similar to the averages of the individual stations. However, since these were regional
Table 1. Comparison of the trends per century from 1981 to 2010 for station and North American Regional Reanalysis (NARR) data sets at Kimball and Sterling. The trend with a plus sign indicates a significant trend at the $p<0.10$ level and an asterisk indicates significance at the $p<0.05$ level.

\begin{tabular}{lcccccc}
\hline & \multicolumn{2}{c}{ Kimball } & & \multicolumn{2}{c}{ Sterling } \\
\cline { 2 - 3 } \cline { 5 - 6 } & Station & NARR & & Station & NARR \\
\hline Maximum temperature $\left({ }^{\circ} \mathrm{C}\right)$ & \multicolumn{2}{c}{3.74} & & \multicolumn{2}{c}{3.26} \\
Average temperature $\left({ }^{\circ} \mathrm{C}\right)$ & - & 2.26 & & - & $4.33^{*}$ \\
Minimum temperature $\left({ }^{\circ} \mathrm{C}\right)$ & $-2.63+$ & - & & $3.64^{*}$ & - \\
Total precipitation $(\mathrm{mm})$ & -185 & 57.6 & & -268 & 64.7 \\
Precipitation as snow $(\mathrm{mm})$ & -97.6 & -48.9 & & $-716^{*}$ & -61.5 \\
Albedo (unitless) & -0.075 & 0.002 & & 0.038 & -0.129 \\
\hline
\end{tabular}

trends, they tended to be much less than what was observed at individual stations as no systematic trends were observed across the entire domain (Fig. 3). Considering the relative terrain homogeneity of the study domain, high levels of spatial and temporal variability suggest a need to understand climate change across the NGP better (Hudson et al., 1983). In a similar terrain and climate, the variability in temperature trends was extensive over a study of eastern Colorado (Pielke Sr. et al., 2002). For example, Fort Collins and Fort Morgan saw significant increases in both $T_{\max }$ and $T_{\min }$, while Kimball saw a less significant increase in $T_{\max }$ but a decrease in $T_{\min }$ (Fig. 2, 3). This highlights the importance of considering the scale of analysis. It is possible that a small increase in the winter temperatures can affect snowfall amounts (Fassnacht et al., 2013). The average annual minimum temperatures for almost all stations in this study remain warmer than freezing (approx. -5 to $10^{\circ} \mathrm{C}$ ). Previous studies have shown that the Northern Great Plains is one of the regions of the United States experiencing increased temperatures as well as a decrease in the amount of annual snowfall (Knowles et al., 2006). The results presented herein include an additional 10 years of data and exhibit less consistency in changes to the amount of snowfall. There has also been a decrease in the ratio of snowfall to rainfall in these regions (Knowles et al., 2006). Feng and $\mathrm{Hu}$ (2007) reported a decrease in the ratio of precipitation as snow at stations in the Northern Great Plains; however, only three of the stations used in this study showed such a decrease (i.e. Harrison, Kimball, Yuma). Previous work (Feng and $\mathrm{Hu}, 2007$ ) also found an overall decrease in the amount of snowfall and an increase in total precipitation; however, this study found more variability regardless of an overall trend in the decrease or increase of snowfall or precipitation.

There is some correlation between trends of the different variables, which could be relevant to albedo as some of them are used in the model. For example, there is a weak correlation between days with snow and maximum or minimum temperature, with $19 \%$ of the variance explained when all 20 trends are used. However, few stations see significant trends among a number of different variables (Fig. 2). For 


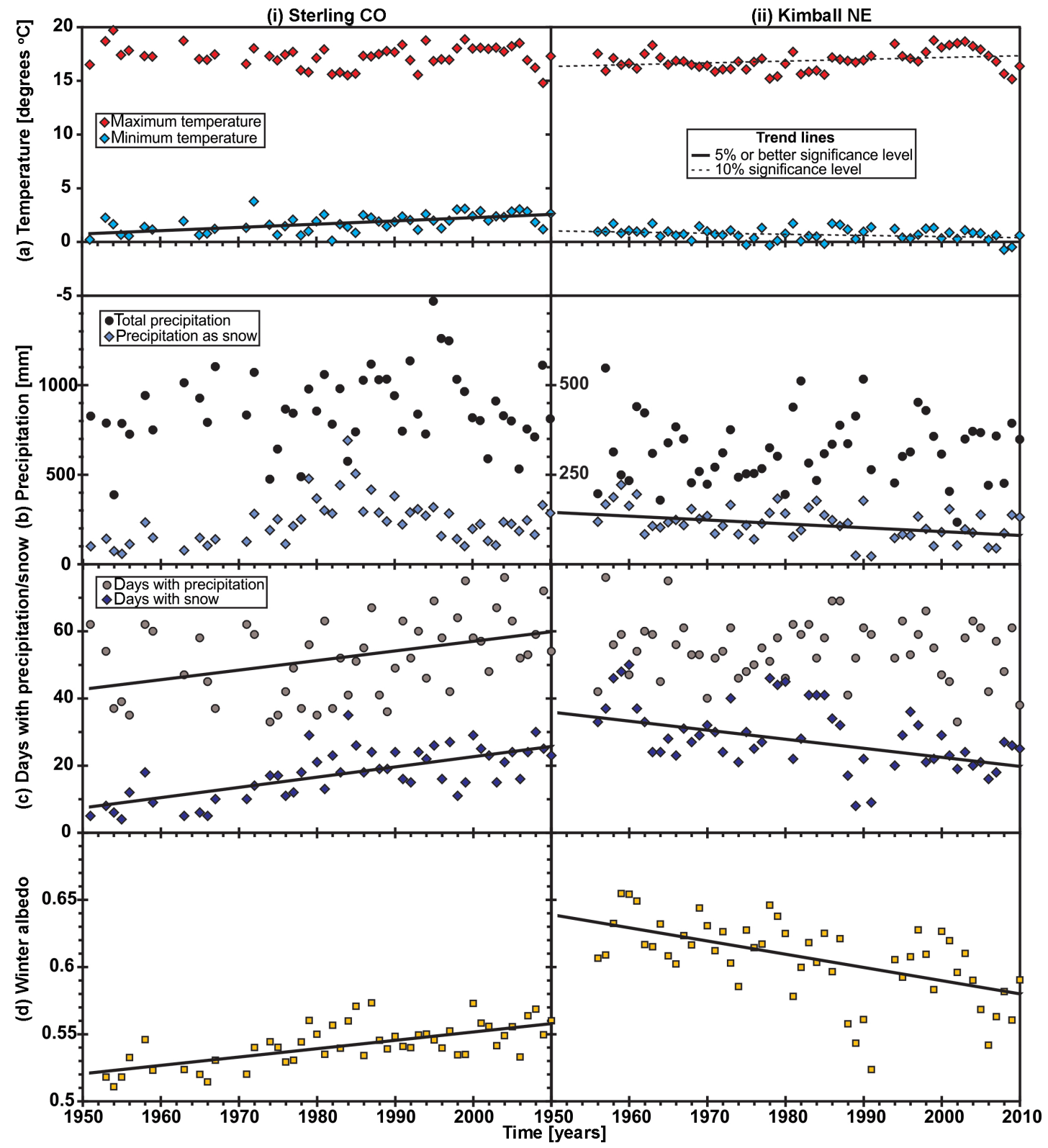

Figure 4. Time series of climate at the neighbouring (i) Sterling, Colorado, and (ii) Kimball, Nebraska, meteorological stations, illustrating (a) temperature (annual maximum and minimum), (b) total annual precipitation and precipitation as snow, (c) days with precipitation and days with snowfall, and (d) winter albedo. Significant trends are shown as solid lines for the $p<0.05$ level and as dashed lines for the $p<0.10$ level. The Kimball station is $73 \mathrm{~km}$ northwest of the Sterling station.

example, seven stations had significant trends in amount of precipitation as snow and minimum temperature, with $24 \%$ of the variance explained. Trends in temperature and precipitation amounts (total and as snow) were not correlated to albedo trends (see Fig. 2).

The length and period of record examined also influences the rates of change and the level of significance (Venable et al., 2012). There was little consistency in the trends over the two 30-year periods (Fig. 5). Of the seven variables, only $T_{\min }$ at Kimball was significantly getting cooler for all time periods (Fig. 5b). Conversely there was strong cooling of $T_{\max }$ early in the period of record, but overall, there was a weaker degree of warming at Kimball. Similarly, at Sterling, $P$ as snow decreased for the first 30 years then increased, yielding a less significant increase overall (Fig. 5). This result may illustrate cyclical trends that become highlighted when analysing shorter time periods (Chen and Grasby, 2009). These trends also somewhat mirror global patterns of cooling from the 1940s to mid-1970s and warming thereafter. 


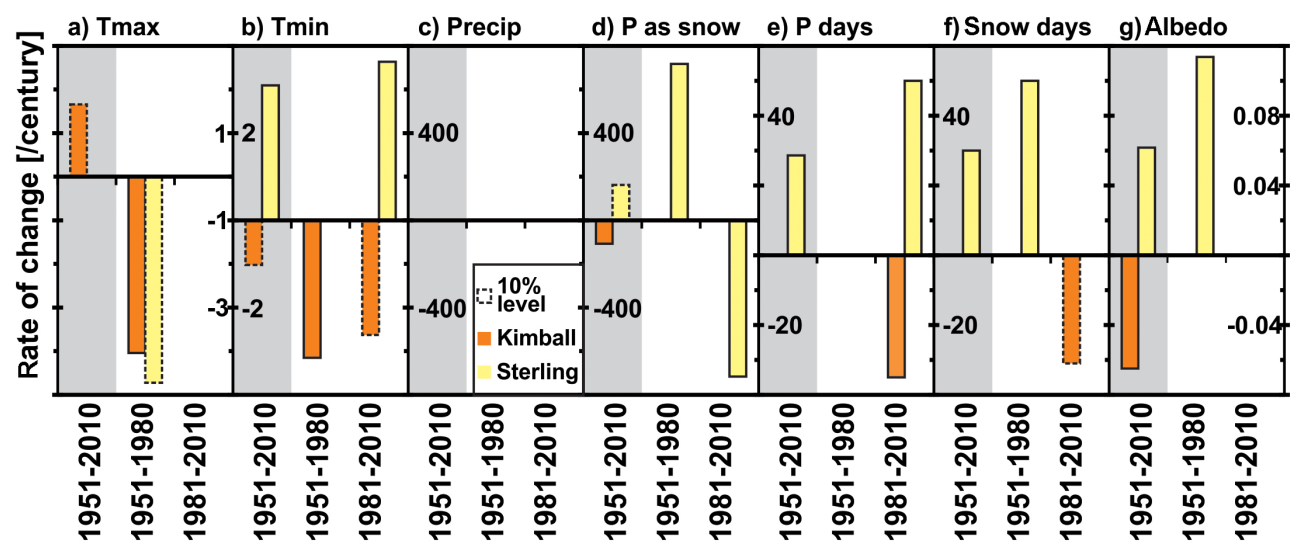

Figure 5. Significant rates of change for the seven variables (a-g) for the two focus stations over varying lengths of record (60 years: 1951-2010 and 30 years: 1951-1980, 1981-2010). There were no significant precipitation trends (c).

Most of the stations did move over the 60 years of data collection, as explained in Sect. 2. Station moves can cause time series discontinuity (Groisman and Legates, 1994; Peterson et al., 1998). While the Sterling station did move about $1.6 \mathrm{~km}$ twice (1983 and 2004), these potential discontinuities are not present in the time series (Fig. 4i). There was a third move in 2010 of about $100 \mathrm{~m}$. There was no indication of changes in the observation time at this station, as that has also been shown to cause discontinuity in time series (Groisman and Legates, 1994; Peterson et al., 1998). It should also be noted that the Northern Great Plains are relatively flat and thus any change in elevation from a station move is negligible. For example, the Goodland station was moved about $500 \mathrm{~m}$, but it remained at the airport so the change in elevation could be assumed to be only in the order of metres.

In climate change modelling efforts, based on data for the northern prairies in Canada, snow-cover duration was less sensitive to temperature changes than in other regions (Brown and Mote, 2009), but trend analyses from the Northern Great Plains for 1910-1993 show high variability in seasonal snow-cover durations. Wintertime increases in snowcover duration were linked with significant increases in seasonal snowfall amounts, though no significant changes were seen in total precipitation (Hughes and Robinson, 1996). It may be that these factors sometimes work together and sometimes at cross-purposes. For example, a warmer winter may be likely to have a shorter snow-cover duration because of melt, or a longer snow-cover duration if there were increases in snowfall during what would normally be the colder winter periods.

Albedo is correlated to snowfall amounts (for example, explained variance of 42 and $45 \%$ for Kimball and Sterling), but albedo is more strongly correlated to days with snowfall (explained variance of 62 and $81 \%$ at the focus sites). This stronger relation is due to the high albedo of fresh snow. While previous studies (e.g. Huntington et al., 2004; Knowles et al., 2006; Feng and Hu, 2007) examined changes in the amount of precipitation as snow, and others examined changes in snow-covered area and duration of snow cover (e.g. Brown and Mote, 2009; McCabe and Wolock, 2010), a quantification of changes in the days with precipitation and days with snowfall is important for understanding changes in albedo. Snow-albedo feedbacks are enhanced by increasing air temperatures and increasing total solar radiation, as occurs in springtime. Hernández-Henríquez et al. (2015) found generally low-magnitude, variably increasing and decreasing fractions of time that mid-latitude sites (such as the NGP) were snow-covered, but conclude that trends of snow-cover extent in late spring and early summer have the greatest impact on the snow-albedo feedback and surface radiation budget input, particularly at higher latitudes. It is thus recommended that days with snowfall be computed as an additional indicator of climate change and that seasonal analysis, particularly of spring data sets, be conducted in spatially and temporally variable snow-covered regions like the NGP. While the arctic regions, especially sea ice regions, and the mountains of the western United States, show an increase in the energy balance for snow- and ice-based regions, there is a possible negative trend for the Northern Great Plains area (Flanner et al., 2011).

The NARR data set was evaluated as it includes albedo data for the second 30-year period of analysis. However, the trends in albedo were of opposite sign and different magnitude (Table 1), but no trends were significant. There was greater interannual variability in the NARR albedo than the station data, but the NARR winter albedo (averaging about 0.31 for the $32 \mathrm{~km}$ pixels about each site) is much less than the modelled station albedo (averaging 0.59 at Kimball and 0.55 at Sterling). For the Northern Great Plains, the maximum surface albedo from the data set compiled by Robinson and Kukla (1985) was from 0.71 to 0.80 ; these data are used to model the NARR data set. The maximum surface albedo was derived at a $1^{\circ}$ (latitude and longitude) resolution from satellite data; there can be a large difference between 
point measurements of albedo and satellite-based estimated due to inhomogeneities such as partial snow cover (Arola et al., 2003). The low values of albedo during snow conditions is consistent among numerous climate/land surface models, even in non-forested areas where the canopy does not need to be considered (Qu and Hall, 2007). Further, the decrease in surface albedo is much more dominated by the melting and thus disappearance of snow, rather than the metamorphism and the addition of meltwater to the surface of the snowpack (Qu and Hall, 2007). New additions to the snow albedo model in the land surface scheme used to generate the NARR data set use a modification of the albedo decay model presented in Eq. (1) (Livneh et al., 2010).

The constant soil albedo of 0.2 can create problems when snow-free conditions persist in the winter months. In the Community Land Model version 4.0, the albedo of soil is a function of colour, wetness, and wavelength, such that it can vary between 0.04 in the visible spectrum for saturated dark soil to 0.61 in the near-infrared region for dry, light soil (Oleson et al., 2010). The identification of soils and vegetation at the 20 stations was not undertaken.

For the Northern Great Plains, the winter albedo of snowfree areas will vary over space, but not necessarily over time due to the dormant nature of the vegetation. In the prairie regions, the grasses can be up to $50 \mathrm{~cm}$ tall, yet will be compressed during snow accumulation, yielding vegetation $10-20 \mathrm{~cm}$ high. Thus $10-20 \mathrm{~cm}$ of snow is required to completely cover such vegetation. However, the data set used herein are collected at airports and near towns with grass areas that are landscaped, thus the vegetation is only $3-5 \mathrm{~cm}$ high which allows it to be buried much quicker than native, non-landscaped prairie vegetation. Formulations do exist to consider the burial of vegetation by snow (e.g. Wang and Zeng, 2009), but this is beyond the scope of this paper.

Using simple snow albedo models is not uncommon; recently the European Centre for Medium-Range Weather Forecasts (ECMWF) was using the snow albedo model presented herein for melting conditions and a linear model for non-melting conditions, based on the Météo-France climate model (Douville et al., 1995). There are limitations in the Verseghy (1991) albedo model since the decrease in $\alpha_{\mathrm{s}}$ is a function of time and air temperature that dictates the state (accumulating or melting) of the snowpack. From the one available data set at the time, Flanner and Zender (2006) illustrated that the default albedo decay coefficient used by Verseghy (1991) was too large; a slower decrease in albedo computed using a smaller decay $\left(k<0.01 \mathrm{~h}^{-1}\right)$ would yield a higher winter albedo when snow was present. Other models, however, could not be used, as snow-specific data were not available for the 60-year period of analysis. Such data include snow particle size or shape, the density of snow, surface temperature, and near-surface temperature gradients. This paper illustrates the influence of changing amounts of snow and the occurrence of snowfall using the available me- teorological data. The latter variable has not been shown in the literature yet.

In the future, more snow data will be available from in situ and remote sensing sources that will allow for the use of more physically based albedo estimates and models. Additional information to improve snow albedo estimates will include the presence of light-absorbing particulates, such as black carbon, dust, and needle litter in forested regions (Flanner et al., 2007; Painter et al., 2007; Boon, 2009). Each of these constituents can play a relevant role in lowering the snow albedo.

\section{Conclusion}

The amount of precipitation falling as snow is changing at a majority of the stations analysed. Trends derived from the Regional Kendall test for all 20 stations showed the dominant trends among the stations but not the local variability. There were more stations with a decrease in the days with snowfall than an increase.

The number of days with snowfall was most important in the modelling of albedo, while the amount of precipitation as snow was less important. Albedo trends mirrored the direction of the trends of the number of snow days at most stations, with albedo decreasing significantly at seven stations and increasing at four others. This affects the winter energy balance.

Temperatures are warming at some of the sites. However, climate trends are not consistent over space or over different time periods, illustrating the relevance of the scale of analysis. There is substantial spatial variability in trends across the study domain, with opposite trends in nearby stations. The period of analysis also influences the significance and rates of change.

Acknowledgements. Thanks to John Stednick of the Colorado State University (CSU) for his input and to the CSU Honors Program for supporting MLC. Partial funding was provided by the NASA Terrestrial Hydrology Program Project award NNX11AQ66G (PI Michael Jasinski NASA GSFC). In-kind funding was provided by the NSF Dynamics of Coupled Natural and Human Systems award BCS-1011801 (PI Maria Fernandez-Gimenez CSU). We would like to thank the handling editor Philip Marsh and two anonymous reviewers for insightful comments that improved this paper.

Edited by: P. Marsh 


\section{References}

Arola, A., Kaurola, J., Koskinen, L., Tanskanen, A., Tikkanen, T., Taalas, P., Herman, J. R., Krotkov, N., and Fioletov, V.: A new approach to estimating the albedo for snow-covered surfaces in the satellite UV method, J. Geophys. Res., 108, 4531, doi:10.1029/2003JD003492, 2003

Boon, S.: Snow ablation energy balance in a dead forest stand, Hydrol. Process., 23, 2600-2610, 2009.

Brown, R., Bartlett, P., MacKay, M., and Verseghy, D.: Evaluation of snowcover in CLASS for SnowMIP, Atmos. Ocean, 44, 223 238, 2006.

Brown, R. D. and Mote, P.: The response of Northern Hemisphere snow cover to a changing climate, J. Climate, 22, 2124-2145, 2009.

Brown, R. D. and Robinson, D. A.: Northern Hemisphere spring snow cover variability and change over 1922-2010 including an assessment of uncertainty, The Cryosphere, 5, 219-229, doi:10.5194/tc-5-219-2011, 2011.

Brun, E., David, P., Sudul, M., and Brunot, G.: A numerical model to simulate snow-cover stratigraphy for operational avalanche forecasting, J. Glaciol., 38, 13-22, 1992.

Chen, Z. and Grasby, S.: Impact of decadal and century-scale oscillations on hydroclimate trend analyses, J. Hydrol., 365, 122-133, 2009.

Clow, D.: Changes in the timing of snowmelt and streamflow in Colorado: a response to recent warming, J. Climate, 23, 22932306, 2010.

Douville, H., Royer, J. F., and Mahfouf, J.F.: A new snow parameterization for the Météo-France climate model, Clim. Dynam., 12, 21-35, 1995.

Fassnacht, S. R. and Soulis, E. D.: Implications during transitional periods of improvements to the snow processes in the land surface scheme - hydrological model WATCLASS, Atmos. Ocean, 40, 389-403, 2002.

Fassnacht, S. R., Sukh, T., Fernández-Giménez, M., Batbuyan, B., Venable, N. B. H., Laituri, M., and Adyabadam, G.: Local understanding of hydro-climatic changes in Mongolia, Cold Region Hydrology in a Changing Climate, in: Proceedings of symposium H02 held during IUGG2011, July 2011, IAHS, Melbourne, Australia, 346, 120-129, 2011.

Fassnacht, S. R., Venable, N. B. H., Khishigbayar, J., and Cherry, M. L.: The Probability of Precipitation as Snow Derived from Daily Air Temperature for High Elevation Areas of Colorado, United States, Cold and Mountain Region Hydrological Systems Under Climate Change: Towards Improved Projections, in: Proceedings of symposium H02, IAHS-IAPSO-IASPEI Assembly, July 2013, IAHS, Gothenburg, Sweden, 360, 65-70, 2013.

Feng, S. and Hu, Q.: Changes in winter snowfall/precipitation ratio in the contiguous United States, J. Geophys. Res., 112, 1-12, 2007.

Flanner, M. G. and Zender, C. S.: Snowpack radiative heating: influence on Tibetan Plateau climate, Geophys. Res. Lett., 32, L06501, doi:10.1029/2004GL022076, 2005.

Flanner, M. G. and Zender, C. S.: Linking snowpack microphysics and albedo evolution, J. Geophys. Res., 111, D12208, doi:10.1029/2005JD006834, 2006.

Flanner, M. G., Zender, C. S., Randerson, J. T., and Rasch, P. J.: Present day climate forcing and response from black carbon in snow, J. Geophys. Res., 112, D11202, doi:10.1029/2006JD008003, 2007.

Flanner, M. G., Shell, K. M., Barlage, M., Perovich, D. K., and Tschudi, M. A.: Radiative forcing and albedo feedback from the Northern Hemisphere cryosphere between 1979 and 2008, Nat. Geosci., 4, 151-155, 2011.

Gilbert, R. O.: Statistical Methods for Environmental Pollution Monitoring, Van Nostrand Reinhold, New York, NY, 336 pp., 1987.

Gray, D. M. and Landine, G. P.: Albedo model for shallow prairie snowcovers, Can. J. Earth Sci., 24, 1760-1768, 1987.

Greuell, J. W. and Konzelmann, T.: Numerical modeling of the energy balance and the englacial temperature of the Greenland ice sheet: calculations for the ETH-Camp location (West Greenland, 1155 m a.s.1.), Global Planet. Change, 9, 91-114, 1994.

Groisman, P. Y. and Legates, D. R.: The Accuracy of United States Precipitation Data, B. Am. Meteorol. Soc., 75, 215-227, 1994.

Groisman, P. Y., Easterling, D. R., Quayle, R. G., Golubev, V. S., Krenke, A. N., and Mikhailov, A. Y.: Reducing biases in estimates of precipitation over the United States: Phase 3 adjustments, J. Geophys. Res., 101, 7185-7195, 1996.

Helsel, D. R. and Frans, L. M.: Regional Kendall test for trend, Environ. Sci. Technol., 40, 4066-4070, 2006.

Hernández-Henríquez, M. A., Déry, S. J., and Derksen, C.: Polar amplification and elevation dependence in trends of Northern Hemisphere snow cover extent, 1971-2014, Environ. Res. Lett., 10, 044010, doi:10.1088/1748-9326/10/4/044010, 2015.

Hoover, J. D., Doesken, N., Elder, K., Laituri, M., and Liston, G. E.: Temporal trend analyses of alpine data using North American regional reanalysis and in situ data: temperature, wind speed, precipitation, and derived blowing snow, J. Appl. Meteorol. Clim., 53, 676-693, 2014.

Hudson, P. D., Miller, G., Jenifer, D., and Hudson, E.: Coptic Times, Track 1 on Rock for Light, PVC Records Number 8917, Caroline, New Jersey, 1983.

Hughes, M. G. and Robinson, D. A.: Historical Snow Cover Variability in the Great Plains Region of the USA: 1910 through to 1993, Int. J. Climatol., 16, 1005-1018, doi:10.1002/(SICI)10970088(199609)16:9<1005::AID-JOC63>3.0.CO;2-0, 1996.

Huntington, T. G., Hodgkins, G. A., Keim, B. D., and Dudley, R. W.: Changes in the proportion of precipitation occurring as snow in New England (1949-2000), J. Climate, 17, 2626-2636, 2004.

IPCC: Climate Change 2007: Synthesis Report, Contribution of working groups I, II and III to the Fourth Assessment Report of the Intergovernmental Panel on Climate Change, edited by: Pachauri, R. K. and Reisinger, A., IPCC, Geneva, 104 pp., 2007.

Knowles, N., Dettinger, M. D., and Cayan, D. R.: Trends in snowfall versus rainfall in the Western United States, J. Climate, 19, 45454559, 2006.

Langlois, A., Bergeron, J., Brown, R., Royer, A., Harvey, R., Roy, A., Wang, L., and Thériault, N.: Evaluation of CLASS 2.7 and 3.5 simulations of snow properties from the Canadian Regional Climate Model (CRCM4) over Québec, Canada, J. Hydrometeorol., 15, 1325-1343, doi:10.1175/JHM-D-13-055.1, 2014.

Livneh, B., Xia, Y., Mitchell, K. E., Ek, M. B., and Lettenmaier, D. P.: Noah LSM Snow Model Diagnostics and Enhancements, J. Hydrometeorol., 11, 721-738, doi:10.1175/2009JHM1174.1, 2010. 
McCabe, G. and Wolock, D. M.: Long-term variability in Northern Hemisphere snow cover and association with warmer winters, Climatic Change, 99, 141-153, 2010.

Menne, M. J., Williams Jr., C. N., and Vose, R. S.: United States Historical Climatology Network (USHCN) Daily Dataset. National Climatic Data Center, National Oceanic and Atmospheric Administration, available at: http://cdiac.ornl.gov/epubs/ ndp/ushen/ushen.html (last access: 13 November 2015), 2015.

Mesinger, F., DiMego, G., Kalnay, E., Mitchell, E., Shafran, P. C., Ebisuzaki, W., Jović, D., Woollen, J., Rogers, E., Berbery, E. H., Ek, M. B., Fan, Y., Grumbine, R., Higgins, W., Li, H., Lin, Y., Manikin, G., Parrish, D., and Shi, W.: North American Regional Reanalysis, B. Am. Meteorol. Soc., 87, 343-360, doi:10.1175/BAMS-87-3-343, 2006.

Mote, P., Hamlet, A. F., Clark, M. P., and Lettenmaier, D. P.: Declining mountain snowpack in Western North America, B. Am. Meteorol. Soc., 86, 39-49, 2005.

Oleson, K. W., Lawrence, D. M., Bonan, G. B., Flanner, M. G., Kluzek, E., Lawrence, P. J., Levis, S., Swenson, S. C., Thornton, P. E., Dai, A., Decker, M., Dickinson, R., Feddema, J., Heald, C. L., Hoffman, F., Lamarque, J.-F., Mahowald, N., Niu, G.-Y., Qian, T., Randerson, J., Running, S., Sakaguchi, K., Slater, A., Stockli, R., Wang, A., Yang, Z.-L., Zeng, X., and Zeng, X.: Technical Description of version 4.0 of the Community Land Model (CLM), NCAR Technical Note NCAR/TN-478+STR, National Center for Atmospheric Research, Boulder, CO, 257 pp., 2010.

Painter, T. H., Barrett, A. P., Landry, C. C., Neff, J. C., Cassidy, M. P., Lawrence, C. R., McBride, K. E., and Farmer, G. L.: Impact of disturbed desert soils on duration of mountain snow cover, Geophys. Res. Lett., 34, L12502, doi:10.1029/2007GL030284, 2007.

Painter, T. H., Deems, J. S., Belnap, J., Hamlet, A. F., Landry, C. C., Udall, B.: Response of Colorado River runoff to dust radiative forcing in snow, P. Natl. Acad. Sci. USA, 107, 17125-17130, doi:10.1073/pnas.0913139107, 2010.

Peel, M. C., Finlayson, B. L., and McMahon, T. A.: Updated world map of the Köppen-Geiger climate classification, Hydrol. Earth Syst. Sci., 11, 1633-1644, doi:10.5194/hess-11-16332007, 2007.

Peng, S., Piao, S., Ciais, P., Friedlingstein, P., Zhou, L., and Wang, T.: Change in snow phenology and its potential feedback to temperature in the Northern Hemisphere over the last three decades, Environ. Res. Lett., 8, 014008, doi:10.1088/17489326/8/1/014008, 2013.

Peterson, T. C., Easterling, D. R., Karl, T. R., Groisman, P., Nicholls, N., Plummer, N., Torok, S., Auer, I., Boehm, R., Gullett, D., Vincent, L., Heino, R., Tuomenvirta, H., Mestre, O., Szentimrey, T., Salinger, J., Førland, E. J., Hanssen-Bauer, I., Alexandersson, H., Jones, P., and Parker, D.: Homogeneity adjustments of in situ atmospheric climate data: a review, Int. J. Climatol., 18, 1493-1517, 1998.
Pielke Sr., R. A., Stohlgren, T., Schell, L., Parton, W., Doesken, N., and Redmond, K.: Problems in evaluating regional and local trends in temperature: an example from eastern Colorado, USA, Int. J. Climatol., 22, 421-434, 2002.

Qu, X. and Hall, A.: Assessing snow albedo feedback in simulated climate change, J. Climate, 19, 2617-2630, doi:10.1175/JCLI3750.1, 2006.

$\mathrm{Qu}, \mathrm{X}$. and Hall, A.: What Controls the Strength of Snow-Albedo Feedback?, J. Climate, 20, 3971-3981, 2007.

Reek, T., Doty, S. R., and Owen, T. W.: A deterministic approach to the validation of historical daily temperature and precipitation data from the cooperative network, B. Am. Meteorol. Soc., 73, 753-762, 1992.

Salmi, T., Määttä, A., Anttila, P., Ruoho-Airola, T., and Amnell, T.: Detecting trends of annual values of atmospheric pollutants by the Mann-Kendall Test and Sen's Slope Estimates, Publications on Air Quality No. 31, Finnish Meteorological Institute, Helsinki, 2002.

Stewart, I. T.: Changes in snowpack and snowmelt runoff for key mountain regions, Hydrol. Process., 23, 78-94, 2009.

US Army Corps of Engineers: Snow Hydrology: Summary Report of the Snow Investigations, North Pacific Division, Portland, OR, 437 pp., 1956.

Venable, N. B. H., Fassnacht, S. R., Adyabadam, G., Tumenjargal, S., Fernández-Giménez, M., and Batbuyan, B.: Does the length of station record influence the warming trend that is perceived by Mongolian herders near the Khangai Mountains?, Pirineos, 167, 71-88, 2012.

Verseghy, D. L.: CLASS - a canadian land surface scheme for GCMs: I. Soil model, Int. J. Climatol., 11, 111-133, 1991.

Vionnet, V., Brun, E., Morin, S., Boone, A., Faroux, S., Le Moigne, P., Martin, E., and Willemet, J.-M.: The detailed snowpack scheme Crocus and its implementation in SURFEX v7.2, Geosci. Model Dev., 5, 773-791, doi:10.5194/gmd-5-773-2012, 2012.

Wang, A. and Zeng, X.: Improving the treatment of vertical snow burial fraction over short 557 vegetation in the NCAR CLM3, Adv. Atmos. Sci. 26, 877-886, doi:10.1007/s00376-5580098098-3, 2009.

Yang, D., Goodison, B. E., Metcalfe, J. R., Golubev, V. S., Bates, R., Pangburn, T., and Hanson, C. L.: Accuracy of NWS 8" standard nonrecording precipitation gauge: results and application of WMO intercomparison, J. Atmos. Ocean. Tech., 15, 54-68, 1998. 